\title{
ANALISIS DEBIT ANDALAN SUNGAI BATANG LUBUH POS DUGA AIR PASIR PENGARAIAN
}

\author{
Annisa Destiany ${ }^{1}$, Manyuk Fauzi ${ }^{2}$, Yohanna Lilis Handayani ${ }^{3}$ \\ 1,2,3 Program Studi Teknik Sipil, Fakultas Teknik, Universitas Riau \\ Kampus Bina Widya Jl. HR Soebrantas KM 12,5 Pekanbaru, Kode Pos 28293 Telp. (0761) 52324 \\ Email: annisa.destiany@student.unri.ac.id,manyuk.fauzi@.unri.ac.id,
}

\begin{abstract}
ABSTRAK
Sungai Batang Lubuh memiliki luas daerah aliran sungai $=1.036 \mathrm{~km}^{2}$ dan menjadi sumber air utama masyarakat Kota Pasir Pengaraian untuk manfaat air baku air minum, irigasi, perikanan dan perkebunan. Analisis debit andalan sungai Batang Lubuh menjadi sangat penting guna diperoleh informasi ketersediaan air pada kondisi basah $\left(\mathrm{Q}_{20 \%}\right)$, normal $\left(\mathrm{Q}_{50 \%}\right)$ dan kering $\left(\mathrm{Q}_{80 \%}\right)$. Analisis dilakukan dengan metode basic month (bulan dasar perencanaan) untuk data pengamatan pos duga air Pasir Pengaraian periode tahun 2011 hingga 2017. Hasil analisis memperoleh nilai-nilai debit andalan pada kondisi musim basah meliputi nilai maksimum $\mathrm{Q}_{20 \%}=199,68 \mathrm{~m}^{3} / \mathrm{dt}$, nilai minimum $\mathrm{Q}_{20 \%}=67,96 \mathrm{~m}^{3} / \mathrm{dt}$, dan rata-rata $\mathrm{Q}_{20 \%}=130,53 \mathrm{~m}^{3} / \mathrm{dt}$. Debit andalan kondisi normal antara lain nilai maksimum $\mathrm{Q}_{50 \%}=151,11 \mathrm{~m}^{3} / \mathrm{dt}$, minimum $\mathrm{Q}_{50 \%}=51,28$ $\mathrm{m}^{3} / \mathrm{dt}$, dan rata-rata $\mathrm{Q}_{50 \%}=91,21 \mathrm{~m}^{3} / \mathrm{dt}$. Selanjutnya untuk debit kondisi musim kering, nilai maksimum $\mathrm{Q}_{80 \%}=95,19 \mathrm{~m}^{3} / \mathrm{dt}$, minimum $\mathrm{Q}_{80 \%}=36,58 \mathrm{~m}^{3} / \mathrm{dt}$, dan rata-rata $\mathrm{Q}_{80 \%}=62,63 \mathrm{~m}^{3} / \mathrm{dt}$.
\end{abstract}

Kata kunci : bulan dasar perencanaan, debit andalan, rokan

\begin{abstract}
Batang Lubuh River has a watershed area $=1,036 \mathrm{~km}^{2}$ and is the main water source for the people of Pasir Pengaraian for municipal water, irrigation, fisheries and plantations. Analysis of the dependable flow of Batang Lubuh river becomes very important in order to obtain information on water availability in wet season $\left(Q_{20 \%}\right)$, normal $\left(Q_{50 \%}\right)$ and dry season $\left(Q_{80 \%}\right)$. The analysis was carried out using the basic month method for observing data on Pasir Pengaraian station for the period of 2011 to 2017. The results of the analysis obtained dependable flow in the wet season including a maximum value of $Q_{20 \%}=199.68 \mathrm{~m}^{3} / \mathrm{s}$, minimum value of $Q_{20 \%}=67.96 \mathrm{~m}^{3} / \mathrm{s}$, and average value of $Q_{20 \%}=130.53 \mathrm{~m}^{3} / \mathrm{s}$. Dependable flow of normal conditions include a maximum value of $Q_{50 \%}=151.11 \mathrm{~m}^{3} / \mathrm{s}$, minimum $Q_{50 \%}=51.28 \mathrm{~m}^{3} / \mathrm{s}$, and average value of $Q_{50 \%}=91.21 \mathrm{~m}^{3} / \mathrm{s}$. Furthermore, for dry season, the maximum value of $Q_{80 \%}=95.19 \mathrm{~m}^{3} / \mathrm{s}$, minimum $Q_{80 \%}=36.58 \mathrm{~m}^{3} / \mathrm{s}$, and average value of $Q_{80 \%}=62.63 \mathrm{~m}^{3} / \mathrm{s}$.
\end{abstract}

Keywords: basic month, dependable flow, rokan

\section{PENDAHULUAN}

Terdapat keunikan air sebagai sumber daya alam jika dibandingkan dengan sumber daya alam lainnya [1]. Keunikan tersebut dikarenakan sifat air yang terbarukan dan dinamis, artinya sumber utama air yang berupa hujan selalu datang pada musimnya sesuai dengan waktu. Akan tetapi, pada kondisi tertentu air bisa bersifat tak terbarukan, misal pada kondisi geologi tertentu dimana proses perjalanan air tanah memerlukan waktu ribuan tahun, sehingga bila pengambilan air tanah dilakukan secara berlebihan, air akan habis.

Ketersediaan air sangat penting dalam kehidupan mahluk hidup. Pemanfaatan air penting untuk kegiatan sehari-hari seperti kebutuhan air rumah tangga, irigasi, industri, dan lain-lain. Dengan demikian, ketersediaan air guna mencukupi sangat diprioritaskan. Ketersediaan air yang kurang mencukupi jika dibandingkan dengan kebutuhan air bersih dapat menimbulkan krisis dan kelangkaan air yang tentu saja menyulitkan masyarakat dalam memenuhi kebutuhan dasarnya sehari-hari. Tantangan kedepan ketersediaan air adalah meningkatnya jumlah populasi manusia, dimana hal tersebut berbanding lurus pada meningkatnya kebutuhan air, padahal menurut siklus hidrologi, jumlah air adalah tetap [2]. Hal ini tentu saja akan menimbulkan masalah di kemudian hari, yakni krisis air. 
Perkembangan dan peningkatan kualitas kehidupan masyarakat Kabupaten Rokan Hulu khususnya Kota Pasir Pengaraian menuntut adanya perbaikan dan penyediaan sarana dan prasarana yang memadai, termasuk ketersediaan air. Kebutuhan air akan semakin meningkat dari tahun ke tahun sejalan dengan pembangunan diberbagai sektor dan bidang pertanian, serta jumlah penduduk yang semakin bertambah. Disisi lain jumlah pasokan air yang ada masih relatif terbatas terutama pada saat musim kemarau [3].

Penyediaan air baku di Kota Pasir Pengaraian Kabupaten Rokan Hulu saat ini masih memanfaatkan sungai sebagai sumber utama untuk memenuhi kebutuhan air. Potensi air pada suatu sungai dapat dikuantifikasikan dalam bentuk hasil air yang optimum, dipandang dari aspek kuantitas dan waktu dapat dipelajari melalui keseimbangan air dinamis berdasarkan masukan dan keluaran air. Dengan demikian, dapat diketahui mengenai ketersediaan air dari waktu ke waktu [4].

Dari permasalahan itu perlu adanya kajian ketersediaan air di sungai atau yang dikenal dengan debit andalan guna pemanfaatan, perencanaan, dan pengelolaan sumber daya air pada kawasan daerah aliran sungai Batang Lubuh dengan outlet pos duga air Pasir Pengaraian.

Perhitungan dan peramalan ketersediaan air di sungai tanpa waduk umumnya dibutuhkan untuk memenuhi kebutuhan air irigasi sebagai kebutuhan mayoritas maka perhitungan ketersediaan air tersebut dihitung berdasarkan kondisi tahun kering atau adalah debit dengan "probabilitas" $80 \%$, yaitu debit dengan kemungkinan tidak terpenuhinya sebesar 20\%, atau dalam jangka 10 tahun akan terjadi 2 kali kegagalan (tidak terpenuhi), debit dengan "probabilitas" tersebut disebut dengan "debit andalan" (dependable flow). Sedangkan untuk perhitungan potensi PLTA, besarnya debit yang harus tersedia ditetapkan berdasarkan analisa debit dengan probabilitas 95\%. Jika hanya tersedia data debit dengan periode data kurang dari 10 tahun, maka harus dilakukan pembangkitan data debit terlebih dahulu, sebelum melakukan perhitungan probobilitas.

Bilamana dalam sistem alokasi air terdapat waduk, ketersediaan air dari waduk perlu ditinjau berdasarkan kondisi pola tahun kering, pola tahun normal dan pola tahun kasah, dan berdasarkan grafik pola operasi waduk (rule curve) dapat diketahui volume air waduk yang dapat dimanfaatkan selain ketersediaan air dari air permukaan (sungai). Demikian pula bilamana pada sistem alokasi air terdapat potensi danau atau air tanah maka perhitungan ketersediaan air selain potensi air permukaan perlu juga untuk memperhatikan potensi yang dapat dimanfaatkan dari air danau dan atau air tanah tersebut.

Perhitungan debit andalan/perhitungan probabilitas dengan lengkung kekerapan dilakukan dengan menggunakan rumus berikut [5]:

$P(X \geq x)=\frac{m-\alpha}{(n+1-2 \alpha)} \times 100 \%$

Dimana :

$\mathrm{P}(\mathrm{X} \geq \mathrm{x})=$ probabilitas terjadinya variabel $\mathrm{X}$ (debit) $\geq x(\mathrm{~m} 3 / \mathrm{dt})$

$\mathrm{n}=$ jumlah data,

$\mathrm{m}=$ peringkat data/nomor urut dari $1 \mathrm{~s} / \mathrm{d}$ jumlah data (n), data debit diurut dari besar ke kecil

$\alpha=$ parameter yang sangat tergantung pada fungsi distribusi dari datanya.

- $\alpha=3 / 8$ (Biom formula, Normal distribusi)

- $\alpha=0.44$ (Gringorten formula, Gumbel distribusi)

- $\alpha=0$ (Weibull Formula)

- $\alpha=1 / 2$ (Hazen Formula)

- $\alpha=2 / 5$ (Cunnane Formula)

Secara teoritis, data ketersediaan air/debit andalan dalam rangka pengelolaan alokasi air dapat dibedakan atas tiga (3) kondisi yaitu:

- Perhitungan untuk menunjang perencanaan pola pengelolaan SDA

- Perhitungan untuk menunjang perencanaan alokasi air tahunan

- Perhitungan untuk menunjang pelaksanaan alokasi air.

Perhitungan ketersediaan air untuk perencanaan POLA Pengelolaan SDA, dan rencana alokasi air tahunan diperlukan seri data debit andalan dalam satu siklus iklim dan atau untuk periode 1 tahun. Perbedaannya antara kedua perencanaan tersebut adalah:

- Guna perencanaan POLA Pengelolaan SDA diperlukan data ketersediaan air di DAS/WS,

- Guna perencanaan alokasi air, diperlukan data ketersediaan air pada setiap titik pengambilan atau pemanfaatan SDA.

Perhitungan ketersediaan air untuk perkiraan debit andalan dalam penelitian ini menggunakan periode bulanan, dimana periode ini sesuai dengan dasar teori bulan dasar perencanaan.

\section{METODE PENELITIAN}

Penelitian ini dilakukan pada sungai Batang Lubuh dengan titik pengamatan aliran pada pos 
duga air Pasir Pengaraian dengan letak geografis 00³5'24" LS dan 101'11'46” BT.

Data yang digunakan dalam penelitian ini adalah data sekunder berupa data curah hujan, data klimatolog dan data debit untuk periode tahun 2008 hingga 2017 yang diperoleh dari Balai Wilayah Sungai Sumatera III dan peta daerah aliran sungai Batang Lubuh dari BPDAS (Badan Pengelolaan Daerah Aliran Sungai) Provinsi Riau, lokasi AWLR Pasir Pengaraian ditampilkan pada Gambar 1.

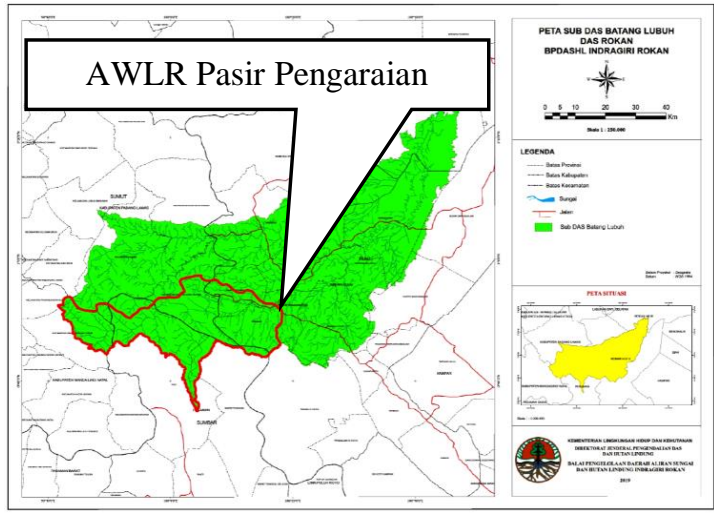

Gambar 1. Peta DAS Batang Lubuh Dengan Outlet AWLR Pasir Pengaraian

Tahapan perhitungan debit andalan dengan lengkung kekerapan adalah sebagai berikut:

a) Kumpulkan data debit dengan atau tanpa interval waktu tertentu yang ditetapkan (bulanan, setengah bulanan, 10 harian, mingguan)

b) Uji data debit/validasi data yang akan dipergunakan

c) Periksa panjang data debit yang valid dan konsisten. Jika data yang tersedia lebih dari 10 tahun dapat langsung digunakan dan jika panjang seri data tersebut kurang dari 10 tahun, perlu dilakukan pengisian atau perpanjangan data.

d) Susun seluruh data debit dari besar ke kecil dan atau sesuai interval waktu yang ditetapkan

e) Tentukan nomor urut data;

f) Hitung probabilitas data sesuai dengan interval waktu yang telah ditetapkan (bulanan/setengah bulanan/sepuluh harian) atau seluruh data yang terekam.

g) Hitung debit andalan berdasarkan probabilitas yang diinginkan, bila probabilitas yang ada tidak sesuai dengan yang diinginkan maka dapat dilakukan interpolasi.

h) Bilamana perlu dihitung debit dengan periode ulang tertentu maka ubah probabilitas debit andalan menjadi debit dengan kala ulang dengan menggunakan rumus [5]:
$T=\frac{1}{(1-P(X \geq x))}=\frac{1}{P(X>x)}$

Dimana :

$\mathrm{T}=$ jumlah tahun yang menunjukkan probabilitas kegagalan (debit yang terjadi $<\mathrm{x} \mathrm{m}^{3} / \mathrm{det}$ ) rata-rata sekali dalam $\mathrm{T}$ tahun, dapat disebut sebagai kala ulang.

$\mathrm{P}=$ adalah probabilitas

Buat kurva durasi debit dengan plot data dari hasil butir d) dan f)

Langkah-langkah yang perlu dilakukan dalam metode basic month (bulan dasar perencanaan) antara lain :

- Data debit yang tersedia disusun sesuai dengan interval waktu yang ditetapkan.

- Cek akurasi dan konsistensi dari seluruh seri data yang tersedia.

- Panjang seri data untuk melakukan analisa lengkung kekerapan harus $\geq 10$ tahun, dan bilamana data yang tersedia $>10$ tahun, maka periode data yang perlu dianalisa adalah seluruh data yang tersedia.

- Data yang tersedia diurut dari besar ke kecil, untuk masing-masing seri data sesuai dengan interval yang telah ditetapkan (dalam hal ini data diurut untuk setiap seri data per bulan). Diagram alir perhitungan kurva durasi debit interval waktu tertentu ditampilkan pada Gambar 2.

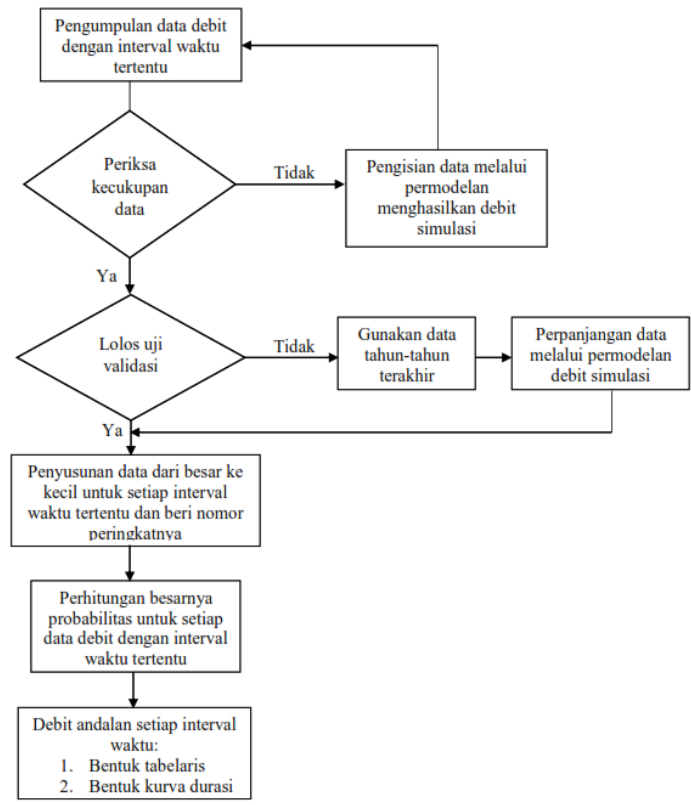

Gambar 2. Diagram Alir Perhitungan Kurva Durasi Debit Interval Waktu Tertentu 


\section{HASIL DAN PEMBAHASAN}

Data curah hujan harian stasiun hujan Pasar Tangun tahun 2008 sampai tahun 2017 ditunjukkan pada Gambar 2. Sedangkan data debit harian dari pos duga air Pasir Pengaraian ditampilkan pada Gambar 3.

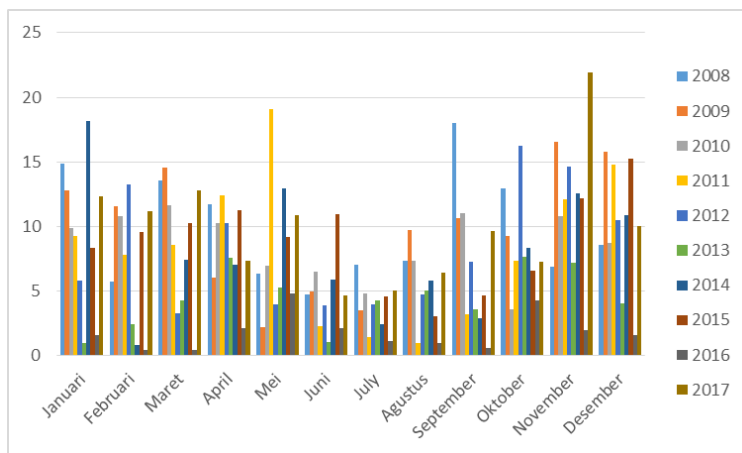

Gambar 3. Curah Hujan Bulanan Stasiun Pasar Tangun (2008-2017)

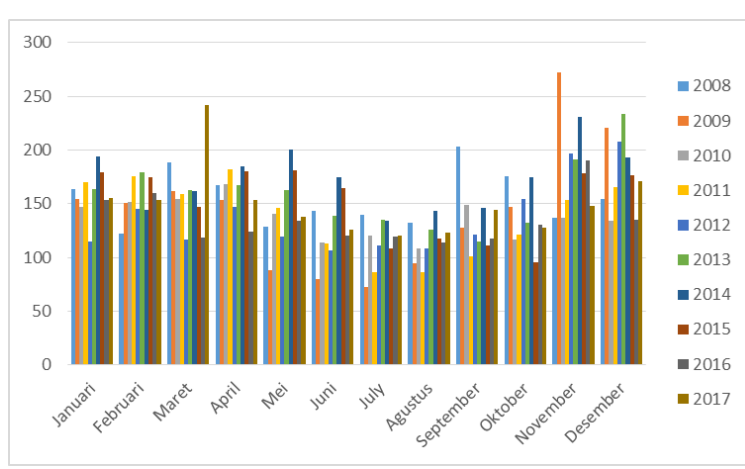

Gambar 4. Debit Bulanan Pos Duga Air Pasir Pangaraian (2008-2017)

Berdasarkan Gambar 2 dan Gambar 3 dapat dilihat terjadi kemiripan pola antara hujan dan debit. Sebelum data digunakan analisis lebih lanjut maka data debit tersebut di atas harus dilakukan uji kualitas data terlebih dahulu. Pengujian dilakukan secara statistik dengan menggunakan metode Rescaled Adjusted Partial Sums (RAPS).

Tabel 1. Uji Konsistensi Data Debit

\begin{tabular}{cccccc}
\hline No & Tahun & $\mathrm{Q}_{\text {tahuman }}$ & $\mathrm{Q}_{\mathrm{i}}-\mathrm{Q}_{\text {rerata }}$ & $\mathrm{Sk}^{*}$ & Sk** $^{* *}$ \\
\hline 1 & 2008 & 103,52 & 8,997 & 8,997 & 0,577 \\
2 & 2009 & 102,35 & 7,831 & 16,828 & 1,080 \\
3 & 2010 & 76,74 & $-17,784$ & $-0,956$ & $-0,061$ \\
4 & 2011 & 83,16 & $-11,361$ & $-12,317$ & $-0,791$ \\
5 & 2012 & 79,46 & $-15,069$ & $-27,385$ & $-1,758$ \\
6 & 2013 & 105,94 & 11,414 & $-15,971$ & $-1,025$ \\
7 & 2014 & 124,90 & 30,377 & 14,405 & 0,925 \\
8 & 2015 & 95,73 & 1,210 & 15,615 & 1,002 \\
9 & 2016 & 76,88 & $-17,648$ & $-2,032$ & $-0,130$ \\
10 & 2017 & 96,56 & 2,032 & 0,000 & 0,000 \\
\hline
\end{tabular}

Adapun prosedur perhitungan uji konsistensi data debit stasiun Pasir Pengaraian tahun 2008 dapat dilihat pada Tabel 1.

a. Pada kolom kedua dari Tabel 1 menunjukkan jumlah hujan tiap tahun pada stasiun Pasir Pengaraian.

b. Selanjutnya diperoleh nilai rata-rata $\left(\mathrm{R}_{\text {rerata }}\right)=$ $94,52 \mathrm{~m}^{3} / \mathrm{dt}$.

c. Menghitung nilai $\mathrm{D}_{\mathrm{y}}$ sebagai berikut : $\mathrm{D}_{\mathrm{Q}}=\sqrt{\frac{\sum\left(\mathrm{Q}_{\text {tahunan }}-\mathrm{Q}_{\text {rerata }}\right)^{2}}{\mathrm{n}}}=15,59 \mathrm{~m}^{3} / \mathrm{dt}$

d. Menghitung statistik $S_{\mathrm{k}} *$ :

$$
\begin{aligned}
& \mathrm{Sk}^{*}=\sum_{\mathrm{i}=1}^{\mathrm{k}}\left(\mathrm{R}_{\mathrm{i}}-\mathrm{R}_{\text {rerata }}\right)=9,00 \\
& \mathrm{Sk}^{* *}=\frac{\mathrm{Sk}^{*}}{\mathrm{D}}=0,58
\end{aligned}
$$

e. Menghitung nilai $Q$ dengan cara:

$\mathrm{Q}=\max _{0 \leq \mathrm{k} \leq \mathrm{n}}\left|\mathrm{Sk}^{* *}\right|=1,08$

f. Menghitung nilai $\mathrm{R}$ dengan cara:

$\mathrm{Ri}=\max _{0 \leq \mathrm{k} \leq \mathrm{n}}|\mathrm{Sk} * *|-\min _{0 \leq \mathrm{k} \leq \mathrm{n}}\left|\mathrm{Sk}^{* *}\right|=2,84$

g. Jika dibandingkan dengan nilai kritik $\mathrm{Q}$ dan $\mathrm{R}$ dari Tabel 1 dengan kepercayaan 90\% maka $\mathrm{Q}_{\text {hitung }}=\frac{\mathrm{Q}}{\sqrt{\mathrm{n}}}=0,34$ sehingga $\mathrm{Q}_{\text {hit }}<\mathrm{Q}_{\text {kritis }}(0,34<$ 1,05). Selanjtnya statistik $\mathrm{R}_{\text {hitung }}=\frac{\mathrm{R}}{\sqrt{\mathrm{n}}}=0,90$ maka $\mathrm{R}_{\text {hitung }}<\mathrm{R}_{\text {kritik }}=0,90<1,21$

Perhitungan di atas, dapat disimpulkan bahwa data debit pos duga air Pasir Pengaraian ini panggah atau konsisten sehingga dapat digunakan dalam analisis selanjutnya. Nilai kritik statistik Q dan R ditunjukkan pada Tabel 2 [6].

\begin{tabular}{|c|c|c|c|c|c|c|}
\hline \multirow{2}{*}{$\mathrm{N}$} & \multicolumn{3}{|c|}{$\mathrm{Q} / \mathbf{n}^{0,5}$} & \multicolumn{3}{|c|}{$\mathbf{R} / \mathbf{n}^{0,5}$} \\
\hline & $90 \%$ & $95 \%$ & $99 \%$ & $90 \%$ & $95 \%$ & $99 \%$ \\
\hline 10 & 1,05 & 1,14 & 1,29 & 1,21 & 1,28 & 1,38 \\
\hline 20 & 1,10 & 1,22 & 1,42 & 1,34 & 1,43 & 1,60 \\
\hline 30 & 1,12 & 1,24 & 1,46 & 1,40 & 1,50 & 1,70 \\
\hline 40 & 1,13 & 1,26 & 1,50 & 1,42 & 1,53 & 1,74 \\
\hline 50 & 1,14 & 1,27 & 1,52 & 1,44 & 1,55 & 1,78 \\
\hline 100 & 1,17 & 1,29 & 1,55 & 1,50 & 1,62 & 1,86 \\
\hline$\infty$ & 1,22 & 1,36 & 1,63 & 1,62 & 1,75 & 2,00 \\
\hline
\end{tabular}

Tabel 2. Nilai Kritik Q dan R 
Selanjutnya dilakukan penyusunan data debit untuk analisis metode bulan dasar perencanaan (basic month). Analisis debit andalan menggunakan metode bulan dasar perencanaan (basic month) hampir sama dengan metode flow characteristic yang dianalisis untuk bulan-bulan tertentu. Metode ini paling sering digunakan karena keandalan debit dihitung mulai bulan Januri hingga bulan Desember. Hasilnya berupa keandalan debit tiap bulan, dan dapat menggambarkan keandalan debit pada musim kemarau (kering) dan musim hujan (basah).

Data debit bulanan hasil pencatatan pos duga air Pasir Pengaraian periode tahun 2011 hingga 2017 ditampilkan pada Tabel 3a dan Tabel 3b. Ratarata debit minimum terjadi di bulan Juli sebesar $51,40 \mathrm{~m}^{3} / \mathrm{dt}$ dan nilai maksimum sebesar 147,43 $\mathrm{m}^{3} / \mathrm{dt}$ yang terjadi di bulan November. Besaran debit untuk masing-masing kondisi dan keandalannya ditampilkan pada Tabel 4a dan Tabel 4b. Rumus empiris untuk menghitung peluangnya digunakan persamaan Weibull sebagaimana persamaan (1).

Tabel 3a. Perhitungan Debit andalan periode bulan Januari-Juni $\left(\mathrm{m}^{3} / \mathrm{det}\right)$

\begin{tabular}{crrrrrr}
\hline Tahun & \multicolumn{1}{c}{ Jan } & \multicolumn{1}{c}{ Feb } & \multicolumn{1}{c}{ Mar } & \multicolumn{1}{c}{ Apr } & May & Jun \\
\hline 2011 & 124,95 & 134,32 & 103,04 & 140,83 & 86,31 & 50,41 \\
2012 & 50,00 & 88,14 & 51,59 & 88,55 & 54,83 & 41,11 \\
2013 & 109,31 & 131,24 & 104,67 & 112,32 & 105,86 & 73,16 \\
2014 & 161,50 & 79,69 & 103,00 & 137,66 & 161,72 & 124,95 \\
2015 & 129,02 & 122,80 & 86,47 & 131,13 & 133,40 & 108,94 \\
2016 & 92,30 & 119,97 & 51,74 & 58,91 & 70,83 & 54,23 \\
2017 & 103,80 & 94,28 & 265,95 & 94,38 & 73,52 & 59,41 \\
\hline Rata-rata & 110,13 & 110,06 & 109,49 & 109,11 & 98,07 & 73,17 \\
\hline
\end{tabular}

Tabel 3b. Perhitungan Debit andalan periode bulan Juli-Desember $\left(\mathrm{m}^{3} / \mathrm{det}\right)$

\begin{tabular}{ccccccc}
\hline \multirow{2}{*}{ Tahun } & Jul & Agt & Sept & Okt & Nop & Des \\
\hline 2011 & 26,84 & 26,84 & 36,62 & 59,59 & 96,55 & 111,65 \\
2012 & 45,63 & 43,07 & 57,07 & 98,65 & 159,43 & 175,39 \\
2013 & 69,13 & 59,90 & 49,83 & 68,60 & 151,11 & 236,12 \\
2014 & 68,03 & 80,05 & 83,28 & 123,04 & 225,15 & 150,73 \\
2015 & 43,28 & 52,90 & 45,86 & 32,85 & 136,30 & 125,85 \\
2016 & 53,42 & 47,58 & 51,28 & 74,39 & 177,37 & 70,49 \\
2017 & 53,46 & 57,72 & 82,24 & 60,97 & 86,07 & 126,87 \\
\hline Rata-rata & 51,40 & 52,58 & 58,03 & 74,01 & 147,43 & 142,44 \\
\hline
\end{tabular}

Tahapan berikutnya adalah menghitung keandalan debit menggunakan peluang Weibull, sebagaimana Tabel 4a dan Tabel 4b.

Tabel 4a. Peluang Weibull dan Urutan Debit dari Besar ke Kecil Periode Januari-Juni ( $\left.\mathrm{m}^{3} / \mathrm{det}\right)$

\begin{tabular}{ccccccc}
\hline Prob. [\%] & Jan & Feb & Mar & Apr & May & Jun \\
\hline $13 \%$ & 161,50 & 134,32 & 265,95 & 140,83 & 161,72 & 124,95 \\
$20 \%$ & 142,01 & 132,47 & 169,19 & 138,93 & 144,73 & 115,34 \\
$25 \%$ & 129,02 & 131,24 & 104,67 & 137,66 & 133,40 & 108,94 \\
$38 \%$ & 124,95 & 122,80 & 103,04 & 131,13 & 105,86 & 73,16 \\
$50 \%$ & 109,31 & 119,97 & 103,00 & 112,32 & 86,31 & 59,41 \\
$63 \%$ & 103,80 & 94,28 & 86,47 & 94,38 & 73,52 & 54,23 \\
$75 \%$ & 92,30 & 88,14 & 51,74 & 88,55 & 70,83 & 50,41 \\
$80 \%$ & 75,38 & 84,76 & 51,68 & 76,69 & 64,43 & 46,69 \\
$88 \%$ & 50,00 & 79,69 & 51,59 & 58,91 & 54,83 & 41,11 \\
\hline
\end{tabular}

Tabel 4b. Peluang Weibull dan Urutan Debit dari Besar ke Kecil Periode Juli-Desember $\left(\mathrm{m}^{3} / \mathrm{det}\right)$

\begin{tabular}{ccccccc}
\hline Prob. [\%] & Jul & Ags & Sept & Okt & Nop & Des \\
\hline $13 \%$ & 69,13 & 80,05 & 83,28 & 123,04 & 225,15 & 236,12 \\
$20 \%$ & 68,47 & 67,96 & 82,66 & 108,41 & 196,48 & 199,68 \\
$25 \%$ & 68,03 & 59,90 & 82,24 & 98,65 & 177,37 & 175,39 \\
$38 \%$ & 53,46 & 57,72 & 57,07 & 74,39 & 159,43 & 150,73 \\
$50 \%$ & 53,42 & 52,90 & 51,28 & 68,60 & 151,11 & 126,87 \\
$63 \%$ & 45,63 & 47,58 & 49,83 & 60,97 & 136,30 & 125,85 \\
$75 \%$ & 43,28 & 43,07 & 45,86 & 59,59 & 96,55 & 111,65 \\
$80 \%$ & 36,70 & 36,58 & 42,16 & 48,89 & 92,36 & 95,19 \\
$88 \%$ & 26,84 & 26,84 & 36,62 & 32,85 & 86,07 & 70,49 \\
\hline
\end{tabular}

Dalam bentuk kurva, maka debit andalan kondisi basah $\left(\mathrm{Q}_{20 \%}\right)$, normal $\left(\mathrm{Q}_{50 \%}\right)$ dan kering (Q80\%) ditampilkan pada gambar-gambar berikut.

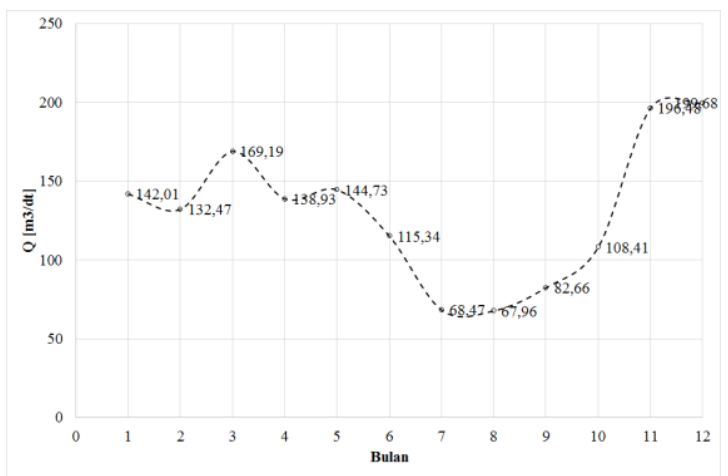

Gambar 5. Debit Kondisi Basah $\left(\mathrm{Q}_{20 \%}\right)$ Pos Duga Air Pasir Pengaraian

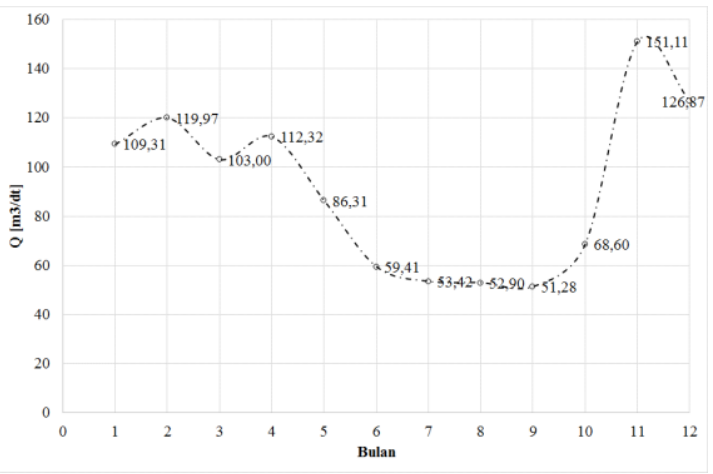

Gambar 6. Debit Kondisi Normal (Q50\%) Pos Duga Air Pasir Pengaraian 


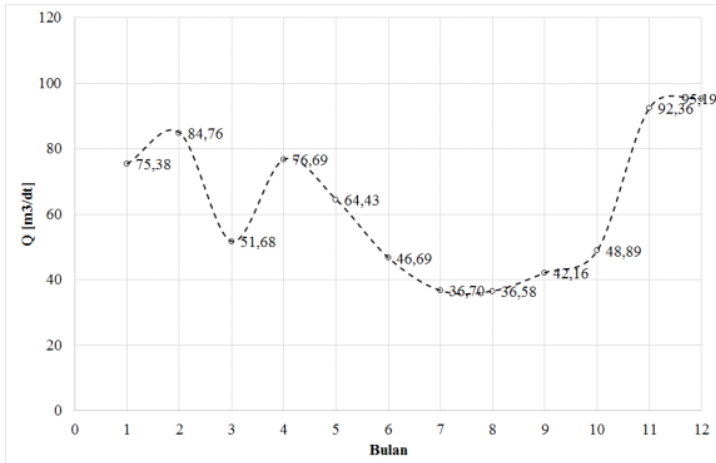

Gambar 7. Debit Kondisi Basah $\left(\mathrm{Q}_{80 \%}\right)$ Pos Duga Air Pasir Pengaraian

Dalam Standar Nasional Indonesia (SNI) 6738:2015 tentang Perhitungan Debit Andalan Sungai Dengan Kurva Durasi Debit disebutkan tentang kurva durasi debit. Standar Nasional Indonesia tersebut menjadi standar perhitungan debit andalan sungai dengan kurva durasi debit yang mengacu pada literatur dan penerapan di beberapa lokasi di Indonesia. Berikut ditampilkan kurva durasi debit untuk masing-masing bulan dengan metode bulan dasar perencanaan.

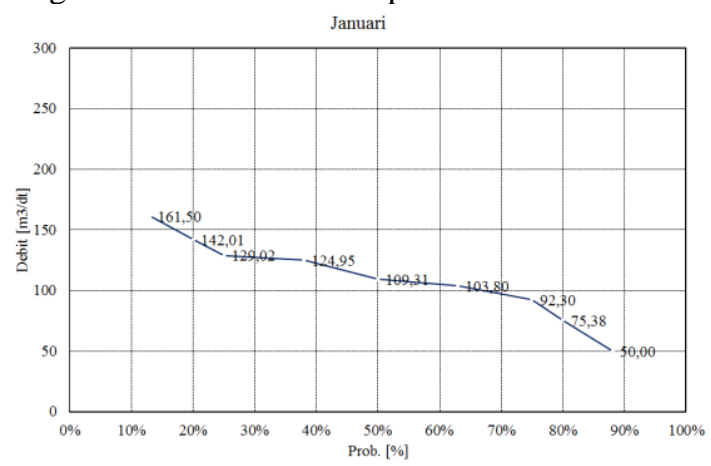

Gambar 8. Kurva Durasi Debit Bulan Januari

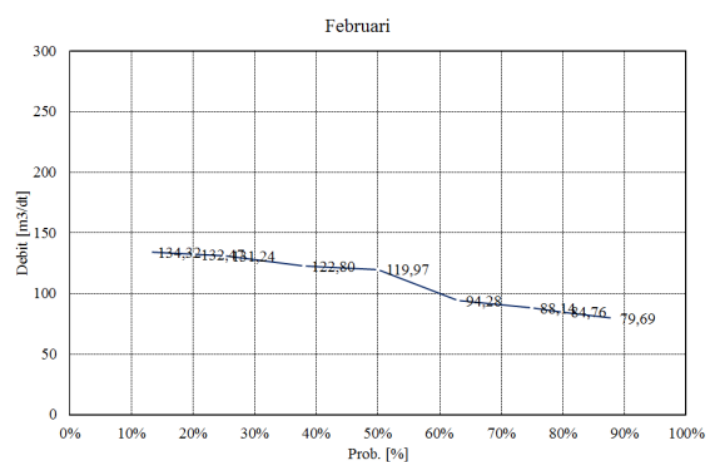

Gambar 9. Kurva Durasi Debit Bulan Februari

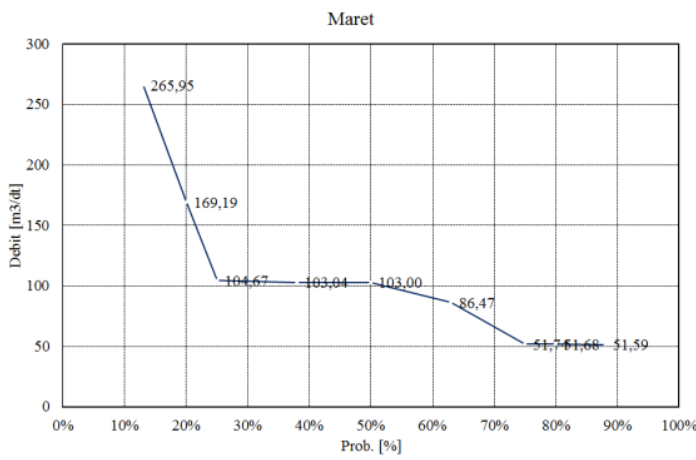

Gambar 10. Kurva Durasi Debit Bulan Maret

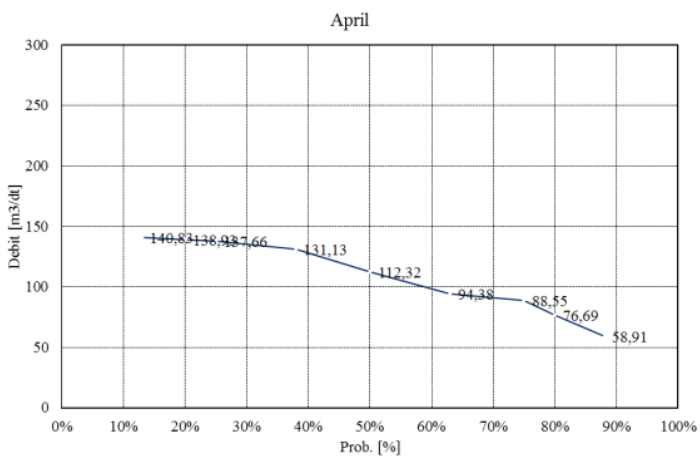

Gambar 11. Kurva Durasi Debit Bulan April

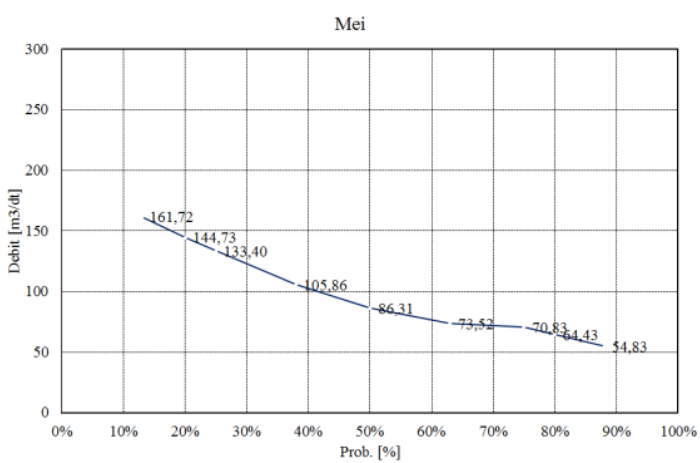

Gambar 12. Kurva Durasi Debit Bulan Mei

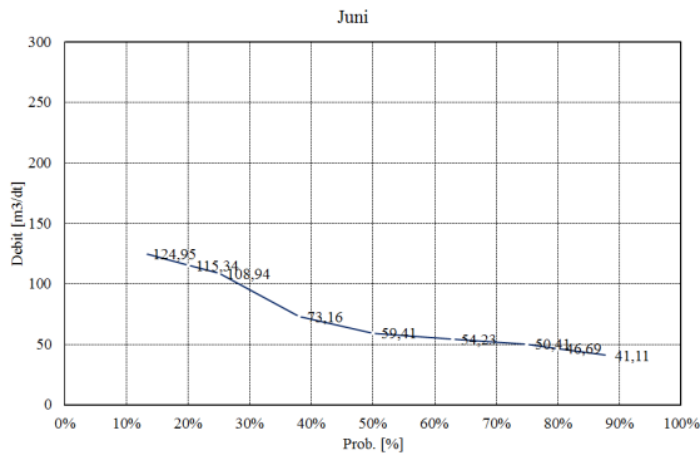

Gambar 13. Kurva Durasi Debit Bulan Juni 


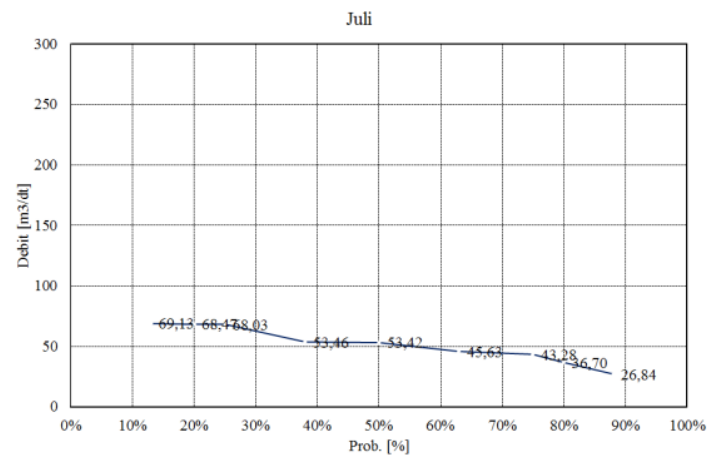

Gambar 14. Kurva Durasi Debit Bulan Juli

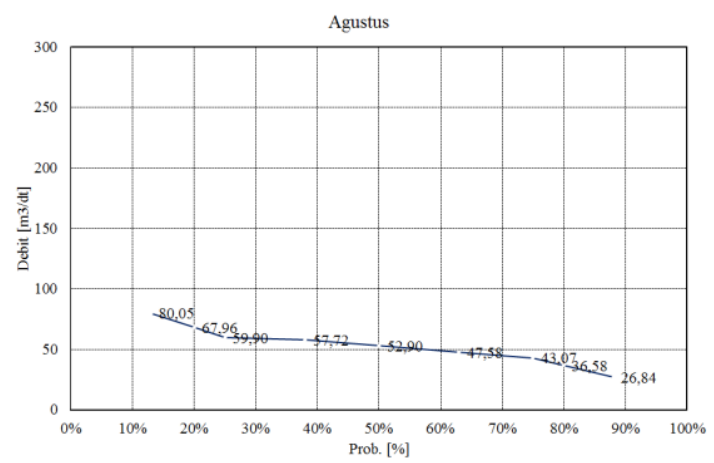

Gambar 15. Kurva Durasi Debit Bulan Agustus

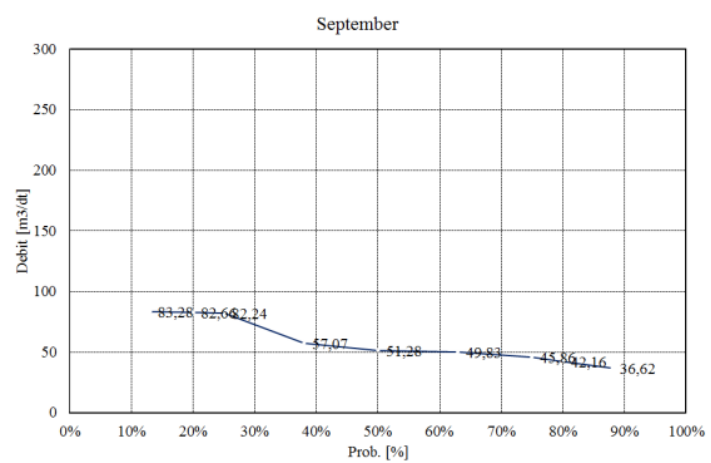

Gambar 16. Kurva Durasi Debit Bulan September

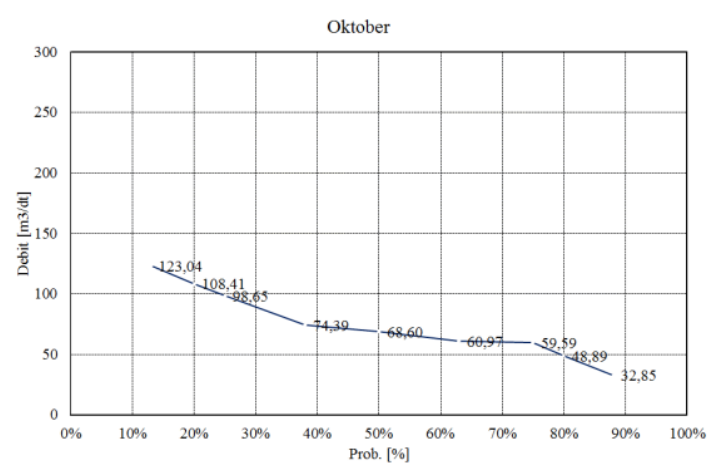

Gambar 17. Kurva Durasi Debit Bulan Oktober

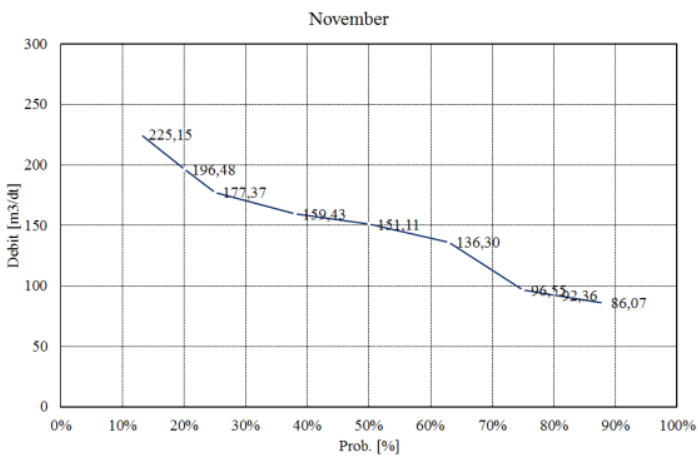

Gambar 18. Kurva Durasi Debit Bulan November

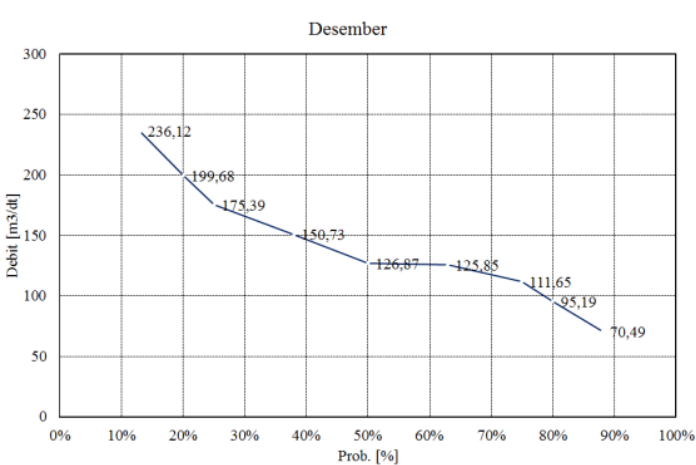

Gambar 19. Kurva Durasi Debit Bulan Desember

Hasil analisis menunjukkan bahwa kondisi debit di Batang Lubuh dapat dikatakan sangat fluktuatif, dimana selisih besaran debit kondisi kering dan kondisi basah mencapai $163,10 \quad \mathrm{~m}_{3} / \mathrm{dt}$ atau 445,87\%. Dapat diindikasikan bahwa saat musim basah kemungkinan besar sering terjadi banjir dan saat musim kering terjadi penurunan muka air yang nyata pada sungai Batang Lubuh. Analisis penggunaan model-model hujan-debit menjadi penting unutk mengetahui kondisi debit andalan pada anak sungai Batang Lubuh. Penggunaan Tank Model menjadi tahap penting berikutnya untuk dikaji. Tank Model merupakan salah satu model konseptual hujan-debit yang umum dimanfaatkan dalam analisis aliran rendah [7].

\section{KESIMPULAN}

Berdasarkan analisis dan pembahasan hasil penelitian maka dapat diambil kesimpulan yaitu, Ketersediaan air pada Sungai batang Lubuh untuk kondisi musim kering $\left(\mathrm{Q}_{80 \%}\right)$, didapatkan debit maksimum sebesar $95,19 \mathrm{~m}^{3} /$ detik terjadi pada bulan Desember dan debit minimum sebesar 36,58 $\mathrm{m}^{3} /$ detik terjadi pada bulan Agustus. Kondisi normal $\left(\mathrm{Q}_{50 \%}\right)$, didapatkan debit maksimum sebesar $151,11 \mathrm{~m}^{3} /$ detik terjadi pada bulan November dan debit minimum sebesar $51,28 \mathrm{~m}^{3} /$ detik terjadi pada bulan September. Sedangkan kondisi musim basah 
(Q20\%), debit maksimum sebesar 199,68 $\mathrm{m}^{3} /$ detik terjadi pada bulan Desember dan debit minimum sebesar 67,96 m³/detik terjadi pada bulan Agustus.

\section{DAFTAR PUSTAKA}

[1] Muchtar \& Abdullah, N. (2007). Analisis Faktor-Faktor Yang Mempengaruhi Debit Sungai Mamasa, 2(1), 174-187.

[2] Kodoatie, Robert J dan Sjarief, Roestam. 2010. "Tata Ruang Air". Yogyakarta : Penerbit Andi

[3] Saputra, W. (2013). Kajian Pemenuhan Kebutuhan Air Baku di Kota Pasir Pengaraian Kabupaten Rokan Hulu, 1-12.
[4] Rudiyanto, Setiawan BI. 2003. Optimasi Parameter Tank Model Menggunakan Genetic Algorithm. Buletin Keteknikan Pertanian 17 (1): 8-16.

[5] Kementerian PUPR, Modul Alokasi Air, Jakrta, 2014

[6] Harto, Sri 1993. Analisis Hidrologi. PT. Gramedia Pustaka Utama, Jakarta.

[7] Song JH, Her Younggu, Park J., Kang MS., "Exploring Parsimonious Daily RainfalRunoff Model Structure Using The Hyperbolic Tangent Function and Tank Model, Journal of Hydrology, Vol. 574, page 574-587, 2019 